\title{
ЮPИДИЧЕСКИЕ HAУRИ
}

\author{
MONOPOLY, COMPETITION AND ENTRY IN THE ELECTRCITY MARKET IN THE REPUBLIC \\ OF UZBEKISTAN
}

\author{
Khusainova Rano \\ Ph.D in Law \\ Doctoral Student (DcS) of Tashkent State University of Law, \\ Tashkent, Uzbekistan \\ DOI: $10.31618 /$ ESU.2413-9335.2020.4.75.849
}

\begin{abstract}
This article offers a perspective on the future of the Electricity System Reform policy currently under way. The article analyzes the use of competitive mechanisms in the electricity markets. The justification of the possibility of competition in the electric power industry and the further development of this concept in practice can be considered particularly significant results of these studies.
\end{abstract}

Keywords: energy, electric energy market, monopoly, competition, market model

\section{Introduction}

The experience of countries around the world clearly shows that the development of the state and society can be achieved only through the electricity market based on contractual relations. Indeed, the strategy of energy reform in Uzbekistan should be aimed at further improving the living standards of the population in the Republic of Uzbekistan, the formation of market relations based on a truly healthy competition, providing a solid guarantee of the right of every individual and legal entity to cheap energy. In the Address of the President to the Oliy Majlis of the Republic of Uzbekistan, it was noted that one of the main tasks in the process of economic reforms is to demonopolize the industry in 2020 , to abolish state regulation of pricing [1]. Generally, the existence of a natural monopoly is interpreted as a "lack of competition" - that is, the existence of several competing firms is associated with situations that are less profitable than the existence of a single firm [2]. Natural monopoly reflects a special type of monopoly, which is explained by the technological features that lead to state intervention in its activities due to the lack of opportunities to create an environment of effective economic competition [3]. As a rule, the monopolistic nature of the behavior of enterprises is explained by the fact that they are the sole supplier of goods and services in the market due to the technological or geographical characteristics of the enterprises in question and are able to meet all existing requirements independently. This peculiarity occurred during the long historical development of infrastructure within natural monopoly enterprises [4]. In this regard, all companies in the fields of electricity and heat transmission, railway transport, transport terminals, ports, airports, public electricity and postal services have been formed as natural monopolies.

Regulated Networks usually have their origins in a natural monopoly. A monopoly is natural when a single seller is the most efficient structure in the relevant industry [5].

The evolution of electricity reform in Uzbekistan

The current energy politics and reforms in the Republic of Uzbekistan are conditionally divided into 4: I - the period of formation of energy independence
(1990-2000), II - the period of the first reforms (20012016), III - the period of radical change (2017-2019), IV - New Uzbekistan energy (2020 - n).

Historically, first, "Uzbekenergo" and "Uzbekgidroenergostroy" have been working to establish an effective management system for enterprises and organizations in the energy and electrification sectors located in Uzbekistan, to improve their structures, to meet the needs of the economy in electricity and heat in the transition to market relations. The Ministry of Energy and Electrification of the Republic of Uzbekistan was established on the basis of the Construction and Assembly Trust and their existing structural subdivisions [6].

In the second phase of energy reforms, the Ministry of Energy and Electrification of the Republic of Uzbekistan was abolished and "Uzbekenergo" - a State Joint-stock Company in the form of an open jointstock company, was established on the basis of its structural subdivisions [7]. Consistent implementation of measures to demonopolize the energy sector in Uzbekistan, reducing the level of state regulation, creating a competitive environment in the sale of electricity have been identified as priorities for deepening economic reforms in the energy sector. The legal basis for the gradual corporatization of large enterprises of the energy sector - thermal power plants, centralized thermal power plants, power grid enterprises, etc., has been created for the introduction of market principles and mechanisms in the management system and economic relations for electricity generation, transmission and sale. Also, the state agency for control over the production, transmission, sale and consumption of electricity, coal mining - the State Agency for Control over Electricity "Uzdavenergonazorat" was established. On September 30, 2009, the Law of the Republic of Uzbekistan "On Electricity" was adopted, aimed at regulating relations in the field of electricity. On March 1, 2013 by the Decree of the President of the Republic of Uzbekistan "On measures to further develop alternative energy sources" on the basis of the Scientific-Production Association "Physics-Sun" of the Academy of Sciences of the Republic of Uzbekistan with the participation of Asian Development Bank and other international 
financial institutions The International Solar Energy Institute was established in Tashkent and the first step was taken to generate energy from renewable sources.

However, it is clear that without ensuring the reliable operation of the electricity sector, it is impossible to increase the industrial potential of industries and regions of the country, stimulate entrepreneurship, improve the welfare of the population and improve quality of life [8]. Also, today, $84 \%$ of the capacity of thermal power plants was commissioned almost half a century ago, and only $83 \%$ of the available capacity is operating [9].

In modern conditions, it is necessary to radically improve the institutional and organizational and legal framework for the development of a competitive environment in the electricity sector and the attraction of investment, production and supply of electricity. In this regard, a completely new era of energy sector reform has begun in our country - a radical turn. Resolution of the President of the Republic of Uzbekistan of May 2, 2017 on the Program of measures for further development of hydropower for 2017-2021, effective use of hydropower potential of the republic, increasing the share of renewable hydropower resources in electricity generation, creation of new environmentally friendly production facilities and for the technical and technological reequipment of existing hydropower plants and the establishment of JSC "Uzbekhydroenergo" to form a unified system of water and energy resources management. Decree of the President of the Republic of Uzbekistan "On the establishment of the joint stock company" Uzbekhydroenergo "and the resolution

"On the organization of the joint stock company "Uzbekhydroenergo" Strengthening energy independence of the country, efficient and safe use of existing hydropower plants, creation of highly maneuverable and efficient new power generation organizations is a huge step towards the creation of a single hydropower sector in Uzbekistan [10]. In 2018, the Republic of Uzbekistan ratified the Paris Agreement (Paris, December 12, 2015). It is expected to provide up to $100 \%$ of the population and the economy with access to modern, cheap and reliable energy [11]. The Law of the Republic of Uzbekistan dated May 21, 2019 "On the use of renewable energy sources" laid the foundation for the production of renewable energy devices. Ensuring the use of electricity by consumers on reasonable and competitive tariffs as the main directions of tariff politics in the electricity sector of the Republic of Uzbekistan; establishment of the principles of pricing for electricity, aimed at ensuring full coverage of operating and capital costs of the power grid organizations during the transition period, the required net profit; the introduction of a stratified tariff after the full introduction of an automated system of metering and control of electricity in all groups of consumers [12]. Also, in 2019, JSC "Uzbekenergo" will be reorganized into a joint-stock company "Thermal Power Stations", which manages thermal power plants and power plants generating electricity and heat, on the basis of JSC "Uzelektrosnab" and the branch "Energosotish" the Regional Electric Networks Joint-Stock Company, which manages the regional power grid enterprises that distribute and sell electricity to final consumers [13].

It is known that in many countries of the world the energy market differs significantly in the composition of entities, the ratio of government intervention and competition, the order of price formation, but mainly focused on a single goal - the introduction of competition in electricity generation and sales.

As a logical continuation of the ongoing reforms in our country, taking into account the best aspects of international experience, the Ministry of Energy of the Republic of Uzbekistan in 2020 in cooperation with the Asian Development Bank and the World Bank is developing a competitive electricity market model. This is an important step in the further development of Uzbekistan, which is being truly renewed in our country, and will create the energy of the New Uzbekistan.

\section{Discussion}

In a monopoly one seller produces the products for an entire market or industry. If the following three factors are present, monopoly pricing and output are likely to occur:

- The entire market is occupied by one seller.

- The product on sale is unique, there is no sufficiently close substitute consumers would turn to in the market.

- $\quad$ Substantial barriers to entry and exit exist.

One of the economic definitions of a (natural) monopoly is the following: "A natural monopoly occurs when economies of scale available in the production process are so large that the relevant market can be served at the least cost by a single firm" [14]. In a monopoly there is potential to abuse consumers as well as potential competitors since the monopolist has the power to set the prices and determine the output. Furthermore, it is likely that a monopoly is inefficient since there is no competition in the market forcing the monopolist to work more efficiently or come up with better standards.

In science, monopoly was first studied by A.A. Cournot, J.S. Mill, K. Marx, L. Walras, A.C. Pigou, A. Marshall, J. Robinson and other scholars as an economic category, which examined the negative effects of monopoly and have scientifically substantiated the issues of combating against them through state regulation. That is, the "theory of state regulation" was created as a scientific basis for state intervention in the activities of natural monopolies, and within the "theory of social welfare" developed mechanisms for regulating natural monopolies aimed at regulating high monopoly prices and increasing consumer surpluses.

The term "natural monopoly" was first introduced into scientific circulation in France by A.Cournot. A.Cournot studied the natural monopoly in terms of establishing control over the use of natural resources. Thus, the concept of "natural monopoly" was based on the definition of the characteristics of the exclusive right to natural resources. A. Cournot acknowledged that if the marginal cost function is reduced, nothing will limit production in the future and a monopoly will be formed [15]. A.Marshall also analyzed the development of industry in Great Britain in the XIX 
century and divided these enterprises into separate groups, called them "way-leaves" and scientifically proved that "way-leaves" is an "insurmountable barrier" to the entry of new companies into a particular field [16].

A monopoly will strive to maximize profits, restrict output and price above marginal cost. The economic theory behind this is in short that if the monopoly charges a price for the product it will only achieve additional sales if it lowers the price on the whole output. Therefore, it is more advantageous for the monopoly to sell fewer products and compensate for the fewer sales by simply charging an increased price for the product. Consequently, a monopoly results in reduced output and higher prices as well as a transfer of income to producers from consumers [17]. The existence of natural monopoly technology was the central reason for establishing regulated industries; thereby introducing entry barriers, obligations to serve and price controls. By asserting that there is a natural monopoly in an industry one at the same time assumes that there is a single best technology. According to commentators the history of natural monopoly justification can be traced back to John Stuart Mill, who in 1848 "emphasized the problem of wasteful duplication of transmission facilities that can occur in utility services" [18]. He also recognized that there are competitive problems when there are only a few competitors in a market: "Where competitors are so few, they always end up agreeing not to compete" [19].

The connection between natural monopolies and regulation was developed by Leon Walras for the construction and operation of railroads [20]. In the early part of the twentieth century the public interest view of regulating utilities was characterized by the assertion that on the one hand regulation was used to capture large-scale productions' efficiencies and on the other hand market power was controlled.

Among the scholars who have studied monopoly and competition from the perspective of the new age are G. Averch, U. Baumol, G. Becker, R. Broytigam, H. Demsetz, L. Johnson, A. Kan, R. Coase, J. Lafont, S. Peltzman, R. Pozner, D. Lorenzo developed new forms and methods of regulating infrastructure networks aimed at limiting the "lack of competition" of the state on natural monopolies. In particular, the reasons for the emergence of monopoly by J. Dupuis were completely different from those studied by earlier scholars. He was one of the first to identify and systematize the causes of the natural emergence of a monopoly situation in the market due to the presence of certain barriers to entry into the market [21] After the Second World War, a modern approach to the definition of natural monopolies was formed, during which the concept of "natural monopoly" was understood primarily as a technological, infrastructure monopoly that produces the necessary products (services) that cannot replace other products. However, in the last quarter of the last century, the approach to the problem of natural monopolies has undergone major changes. In particular, the changes in electricity generation during this period are the most striking example.
Thus, by the 80 s of the twentieth century, as a result of the development of production technologies, the practice of energy saving at the expense of increasing the single capacity of power plant units was almost completed. At the same time, the efficiency of nuclear energy was related to the unresolved problems of waste disposal, the level of safety and the negative attitude in society. Under such conditions, the launch of a new generation of production capacity on the basis of the establishment of steam and gas stations laid the foundation for the emergence of independent electricity producers. Thus, small power plants have been recognized as cost-effective and attractive to investors due to their environmental friendliness, short construction time, and low prices for $1 \mathrm{~kW}$ of power [22]. The World Bank's assessment of small-scale energy as a promising method of energy supply has, in theory, allowed us to talk about the narrowing of traditional ideas about natural monopolies, as this has demonstrated that there is an alternative way to produce natural monopoly goods and services and organize competition. In particular, the structure of the network, the asymmetry of the data and the presence of strong vertical technological connections limit the opportunities for competition in natural monopoly networks [23]. Analysis of technological changes in a number of areas shows that these changes have affected the basic conditions for the existence of natural monopolies in industry and, as a result, changed the nature and manifestation of natural monopolies in modern conditions, replacing traditional methods of regulating natural monopolies with competitive mechanisms (in whole or in part). scientific views emerged. The basis of these changes was the introduction of competitive relations and a paradigm shift in the regulation of natural monopolies - the transition from price regulation to the regulation of competition and market relations. Reform models for complex multi-product companies are based on the principles of demonopolization, restructuring, and reorganization.

Deregulation was justified by the end of natural monopoly technology. If one firm is able to supply at a lower cost, the market than two or more firms, a production technology exhibits the property of a natural monopoly. However, due to technological developments there exists much less natural monopoly technology nowadays.

It is known that although the composition of natural monopolies varies in foreign countries, in recent years there have been similarities in most countries in the direction of shrinking the scope of natural monopolies. The spheres of natural monopolies in Uzbekistan are much wider than in international practice, and their formation is accompanied by the structures that emerged in the transition period for the reconstruction and management of the economy [24]. Because in Uzbekistan, as well as in the countries of the former Soviet Union, which for a long time was under the influence of Soviet ideology, energy, heat and gas supply was defined as the responsibility of the state, the state played a leading role in organizing the energy sector. 
According to Article 3 of the Law of the Republic of Uzbekistan "On Natural Monopolies" of August 19, 1999, a natural monopoly means that due to the technological features of the commodity market it is impossible or economically feasible to create competitive conditions for certain types of goods (works, services). and, accordingly, the subject of a natural monopoly is a business entity (legal entity) engaged in the production (sale) of goods in a natural monopoly [25]. According to the President, "the state regulates the prices for 37 types of goods and services, which has a negative impact on free competition. With this in mind, we should now focus not on setting prices, but on reducing prices and improving quality by ensuring healthy competition among businesses. It is necessary to study the international experience and open the way for the private sector to monopolize areas where competition can be introduced, and thus create a competitive environment. In this regard, it is necessary to update the laws on natural monopolies and competition and to develop a strategy for creating a competitive environment in the economy. Simply put, we need to be in sync with global production chains, world market demands, and economic integration processes. Public-private partnership mechanisms, which are one of the most effective means of attracting investment, should be widely applied in such areas as transport, energy, roads, utilities, medicine, education" [26].

One of the priorities of state economic policy in the field of natural monopolies is their structural reorganization, the transfer of natural monopolies to the market, which helps them to operate more efficiently [27].

\section{Results}

Summarizing the world experience in electricity reform, the following main models of the electricity market can be identified:

1) vertical integrated model - the process from generation to sale of electricity is carried out within an integrated company, prices are regulated by tariffs (France);

2) single-buyer model - as a system operator, the Single Buyer buys electricity from independent energy producers on a long-term contract at regulated prices (Austria); This model is a transition from the vertically integrated model to the Retail Market model.

3) wholesale market or independent producer model - a vertically integrated model based on a natural monopoly in the field of energy transmission and distribution in the presence of competition between producers (Australia, UK, Spain);

4) competitive model - the most liberal model, in which the pricing of energy in the wholesale and retail markets of electricity is carried out on a competitive basis (Germany, Japan, Finland) [28].

These models of reorganization of the electricity sector have been sufficiently studied by economists and technical scientists. It should be noted that none of these models exist in practice in their pure form, but are implemented step by step.

In our opinion, the model of the energy market in Uzbekistan should be focused on issues such as removing all barriers in the field of small energy production and radically changing the rules of energy transmission and sales, which will allow the society to conclude agreements with the wholesale and retail markets. This situation also increases the convenience for consumers in choosing an energy supplier, resulting in increased competition between energy supply organizations in the wholesale and retail markets. Despite the existence of competitive prices in the wholesale and retail energy markets, the state retains direct and indirect regulatory functions. At the level of energy supply and distribution subsystems, the state can own capital assets and be able to directly regulate their use and pricing methods. The main important result of the reforms in the sector, in particular, any model of organization of the electricity industry, is that the country will be able to use the energy sector on a free choice by consumers for domestic or industrial use. This indicator reflects the level of competition in the production and sale of electricity.

\section{Conclusion}

In the end based on the above mentioned arguments I came to the conclusion that the choice of a particular model of organization of the industry depends on many factors, but two main ones - the existing relationships in the industry and the ownership structure are of particular importance. In particular, we can conclude that the reform of the existing vertical structure of the energy industry in the country and the introduction of competition in practice cannot be ensured without amending the legislation of this country, even the Constitution.

First, energy should be assessed as an independent sector that systematically covers not only the electricity sector, but also the oil, gas, coal, heat, nuclear, hydropower and renewable energy sectors, which should be developed in parallel.

Second, a market model based on healthy competition should be approved in Uzbekistan as a guarantee of the right of every individual and legal entity to cheap energy in the future.

Third, the need to adopt a legislative system aimed at constitutionally guaranteeing everyone's right to energy in the future should be noted.

Fourth, given the participation of several independent entities in the energy supply in the market model of energy, it should be noted that the Civil Code should include new systemic norms that fully regulate each contractual relationship between energy entities, the legal regime of each contract.

Fifth, it is necessary to determine the introduction of decentralized electricity generation in the country and the procedure for its licensing, the priorities of the transition to digital energy, the introduction of certification for the transition to a new tariff system for energy consumption.

In conclusion, the first guarantee of market relations in the energy sector is, first of all, the reduction of natural monopolies in the energy sector and the formation of a competitive environment in energy production.

\section{References:}

1.Mirziyoyev Sh.M. The Text of President's Address to the Oliy Majlis of the Republic of 
Uzbekistan (2020) https://uza.uz/oz/politics/zbekistonrespublikasi-prezidenti-shavkat-mirziyeevning-oliy25-01-2020

2.Jacques S. Natural monopolies: problems of definition and control

https:cyberleninka.ru/article/n/estestvennye-

monopolii-problemy-opredeleniya-i-kontrolya

3.Trachuk A.V. (2006) Natural monopolies and competition Newspaper "Energy and Industry of Russia”. Energy // www.eprussia.ru/epr/76/5235.htm

4.Kononkov P.F. (2007) State regulation of natural monopolies: the dissertation ... of the candidate of economic sciences: 08.00.01 Moscow, 159 p. RSL OD, 61: 07-8 / 2666

5.Kwoka, Networks and natural monopoly in Moss, Network Access, Regulation and Antitrust (2009) 17.

6.Decree of the President of the Soviet Socialist Republic of Uzbekistan № PF-57 of 28 September 1990 "On Improving the Ministry of Energy and Electrification of the Socialist Republic of Uzbekistan" // (Bulletin of the Supreme Council of the Soviet Socialist Republic of Uzbekistan, № 33, 28-30, 1990)

7.Decree of the President of the Republic of Uzbekistan № PF-2812 of 22 February 2001 “On deepening economic reforms in the energy sector of the Republic of Uzbekistan" // Bulletin of the Oliy Majlis of the Republic of Uzbekistan, 2001, № 1-2, Article 47; 2012, № 40, Article 466

8.Resolution of the President of the Republic of Uzbekistan "On the strategy for further development and reform of the electricity sector in the Republic of Uzbekistan" // National Database of Legislation, 28.03.2019, No 07/19/4249/2840

9.Issues of further development of the electricity sector // https://president.uz/uz/2066

10.Decree of the President of the Republic of Uzbekistan dated May 18, 2017 "On the establishment of the joint stock company" Uzbekhydroenergo "// Collection of Legislation of the Republic of Uzbekistan, 2017, № 21, Article 378; National Database of Legislation, 28.11.2018, № 06/18/5586/2230

11.STRATEGY of transition of the Republic of Uzbekistan to the "green" economy for the period 2019. 2030, approved by the Resolution of the President of the Republic of Uzbekistan dated October 4, 2019 No PP-4477. APPENDIX 1 to the Resolution of the President of the Republic of Uzbekistan № PP-4477 of October 4, 2019 // National Database of Legislation, October 5, 2019, № 07/19/4477/3867

12.Resolution of the Cabinet of Ministers of the Republic of Uzbekistan dated April 13, 2019 № 310 "On additional measures to improve tariff policy in the electricity sector" // National Database of Legislation, 15.04.2019, № 09/19/310/2948

13.Resolution of the President of the Republic of Uzbekistan dated March 27, 2019 No PP-4249 "On the Strategy for further development and reform of the electricity sector in the Republic of Uzbekistan" // National Database of Legislation, 28.03.2019, № 07/19/4249 / 2840

14.Baldwin, Understand Regulation - Theory, Strategy and Practice2 (2012). Bell, Broadband
Deregulation - Similar Legislation, Different Results: A Comparative Look at the United States and the European Union: Tulane Journal of Technology and Intellectual Property (Fall 2007) 77.

15.Cournot A. Recherches sur les Principes Mathematiques de la Theorie des Richesses // Augustus M. Kelly. - 196, p. 91.

16.Marshall A. (1890) Principles of Economics (8th ed.)

17.Baldwin, Understand Regulation 443- 444.

18.Sidak/Spulber, Deregulatory Takings and the Regulatory Contract - The Competitive Transformation of Network Industries in the United States (1997) 20-21.

19.Stigler, The Economists and the Problem of Monopoly, in Occasional Papers from The Law School the University of Chicago, no.19 (1982), 1 (4).

20.Walras, Etudes d'Economie Sociale: Theorie de la Repartition de la Richesse Sociale (1896). 77.

21.Dupuit J. (1837) Essai et expériences sur le tirage de voitures et sur le frottement de second espèce. - Paris: Carilian - Goeury, 167 p.; Dupuit J. (1993) On the measure of utility of civil structures. - Theory of consumer behavior and demand. - SPb., p. 49.

22.Petrovsky E.S. (1999) Competition in the electric power industry: Western experience and the problems of Russia. / Materials of the international scientific-practical conference "Actual problems of management-99". Vol 1., M.: Publishing house of GUU, p. 89-90.

23.Trachuk A.V. (2006) Natural monopolies and competition Newspaper "Energy and Industry of Russia” № 12 (76) December. Energy // www.eprussia.ru/epr/76/5235.htm

24.https://qomus.info/encyclopedia/cat-t/tabiiymonopoliya-uz/.

25.Law of the Republic of Uzbekistan "On Natural Monopolies". August 19, 1999 // (Bulletin of the Oliy Majlis of the Republic of Uzbekistan, 1999, № 9, Article 212; Collection of Legislative Acts of the Republic of Uzbekistan, 2006, № 41, Article 405; 2007 , 50-51 - Article 499; 2010, № 50, Article 470; 2013, № 18, Article 233, № 41, Article 543; 2014, № 50, Article 588; 2016, № 17, Article 173)

26.Mirziyoev Sh.M. "Ensuring macroeconomic stability and curbing inflation is our main task in the process of economic reforms" //http://xs.uz/uzkr/post/shavkat-mirziyoev-

macroeconomics is our main task

27.https://qomus.info/encyclopedia/cat-t/tabiiymonopoliya-uz/

28.Kamashev A.A. (2011) Comparative analysis of models of functionalization of electric power industries in Russia and the world in the context of reform processes // "Rossiyskoe predprinimatelstvo" // https://cyberleninka.ru/article/n/sravnitelnyy-analizmodeley-funktsionirovaniya-elektroenergeticheskihotrasley-v-rossii-i-mire-v-kontekste-protsessovreformirovaniya/viewer; Balandin D.V. Structure and features of the power market: interstate analysis // Bulletin SPbGU. https://cyberleninka.ru/article/n/struktura-iosobennosti-rynka-elektroenergii-mezhstranovyyanaliz-na-primere-ryada-stran-chlenov-oesr-1 